\title{
Correction to: Classification of topography for ground vulnerability assessment of alluvial plains and mountains of Japan using $30 \mathrm{~m} \mathrm{DEM}$
}

\author{
Junko Iwahashi ${ }^{i^{*}}$, Dai Yamazaki ${ }^{2}$, Takayuki Nakano ${ }^{1}$ and Ryo Endo ${ }^{1}$
}

\author{
Correction to: Prog Earth Planet Sci 8, 3 (2021) \\ https://doi.org/10.1186/s40645-020-00398-0
}

Following publication of the original article (Iwahashi et al. 2021), the authors identified an error in Fig. 6. The correct Fig. 6 is given below. The authors would like to correct the cited author name under the heading Base classification using $\mathrm{k}$-means clustering and thresholding.

The sentence currently reads:

The efficacy of using polygons, i.e., terrain or slope units, as a criterion for classification has been noted by a number of researchers (Alviolicor et al. 2020).

The sentence should read:

The efficacy of using polygons, i.e., terrain or slope units, as a criterion for classification has been noted by a number of researchers (Alvioli et al. 2020).

The original article (Iwahashi et al. 2021) has been corrected.

\footnotetext{
Author details

'Geospatial Information Authority of Japan (GSI of Japan), Kitasato-1, Tsukuba, Ibaraki 305-0811, Japan. ${ }^{2}$ Institute of Industrial Science, The

University of Tokyo, Komaba 4-6-1, Meguro-ku, Tokyo 153-8505, Japan.
}

Published online: 02 March 2021

\section{Reference}

Alvioli M, Guzzetti F, Marchesini I (2020) Parameter-free delineation of slope units and terrain subdivision of Italy. Geomorphology 358:107124. https://doi.org/1 0.1016/j.geomorph.2020.107124

The original article can be found online at https://doi.org/10.1186/s40645020-00398-0.

*Correspondence: iwahashi-j96pz@mlit.go.jp

${ }^{1}$ Geospatial Information Authority of Japan (GSI of Japan), Kitasato-1,

Tsukuba, Ibaraki 305-0811, Japan

Full list of author information is available at the end of the article

型 Springer Open

(c) The Author(s). 2021 Open Access This article is licensed under a Creative Commons Attribution 4.0 International License, which permits use, sharing, adaptation, distribution and reproduction in any medium or format, as long as you give appropriate credit to the original author(s) and the source, provide a link to the Creative Commons licence, and indicate if changes were made. The images or other third party material in this article are included in the article's Creative Commons licence, unless indicated otherwise in a credit line to the material. If material is not included in the article's Creative Commons licence and your intended use is not permitted by statutory regulation or exceeds the permitted use, you will need to obtain permission directly from the copyright holder. To view a copy of this licence, visit http://creativecommons.org/licenses/by/4.0/. 
The source data of FGD as of July 2017

Airborne $\operatorname{LiDAR}\left(0.2^{n} \approx 5 \mathrm{~m}\right)$

Photogrammetry $\left(0.2^{n} \approx 5 \mathrm{~m}\right)$

$\square$ Topographic contours $\left(0.4^{m} \approx 10 \mathrm{~m}\right)$
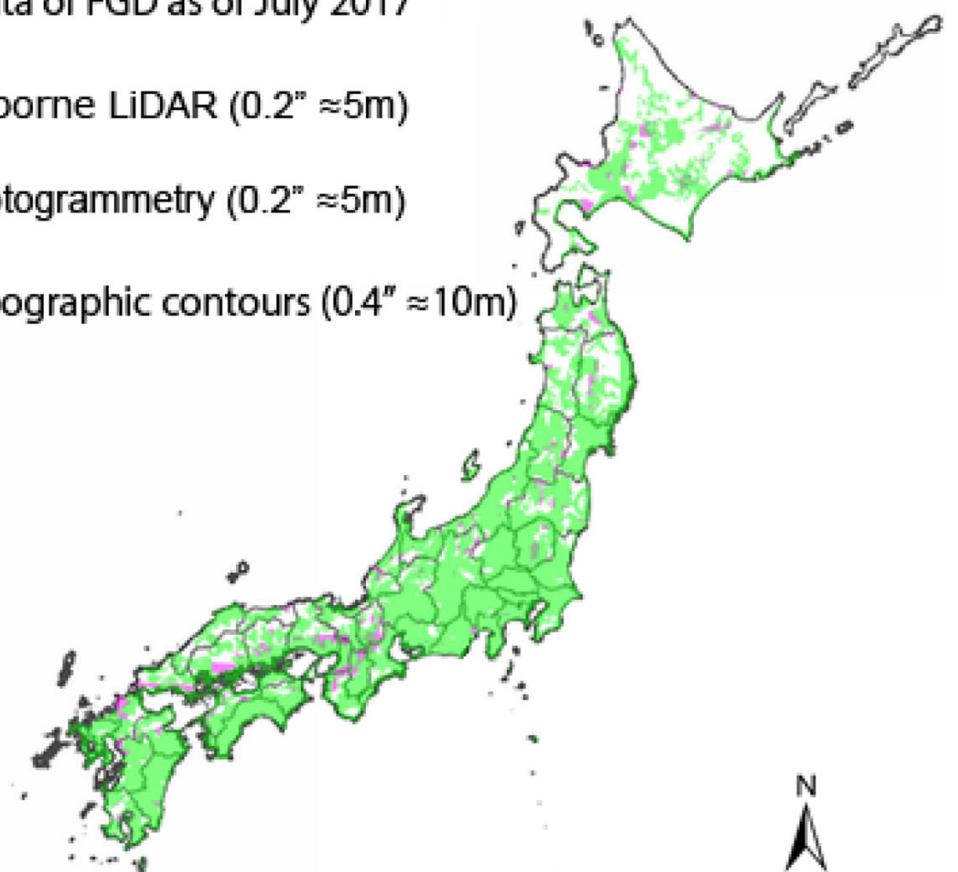

o

$300 \mathrm{~km}$

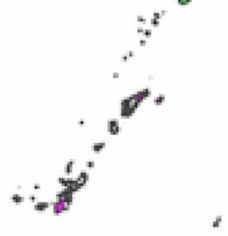

Fig. 6 Types of the source data of the DEM (FGD) used in this study 